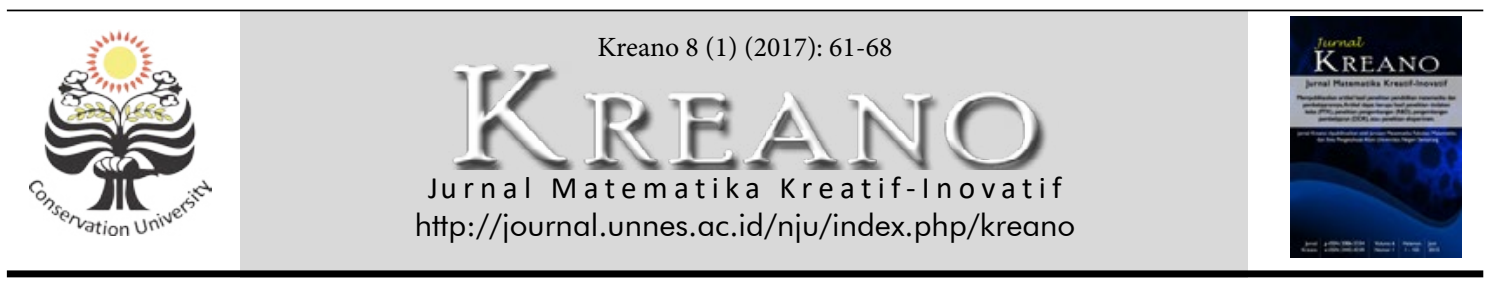

\title{
Peranan Pengetahuan Awal dan Self Esteem Matematis Terhadap Kemampuan Berpikir Logis Mahasiswa
}

\author{
Aan Subhan Pamungkas', Yani Setiani ${ }^{2}$ \\ 'Jurusan Pendidikan Matematika, FKIP, Universitas Sultan Ageng Tirtayasa, Indonesia \\ Email: asubhanp@untirta.ac.id',yanisetiani@untirta.ac.id²
}

DOI: http://dx.doi.org/10.15294/kreano.v8i2.7866

Received: November 2016; Accepted: January 2017; Published: June 2017

\begin{abstract}
Abstrak
Penelitian ini bertujuan untuk mengkaji peranan pengetahuan awal, self esteem matematis dan kemampuan berpikir logis. Penelitian ini merupakan penelitian korelasional dengan pendekatan kuantitatif. Populasi sekaligus sampel dalam penelitian ini adalah seluruh mahasiswa Jurusan Pendidikan IPA FKIP Universitas Sultan Ageng Tirtayasa tahun pertama berjumlah 34 mahasiswa yang diambil dengan teknik simple random. Teknik pengumpulan data menggunakan tes pengetahuan awal dan kemampuan berpikir logis serta skala self esteem matematis. Analisis data dalam penelitian ini adalah dengan analisis statistic deskriptif untuk mengetahui gambaran ketiga variabel tersebut dan analisis regresi ganda serta anova satu jalur untuk melihat pengaruh variable pengetahuan awal dan self esteem matematis terhadap kemampuan berpikir logis serta analisis anova satu jalur untuk melihat perbedaan kemampuan berpikir logis ditinjau dari pengetahuan awal dan self esteem matematis. Berdasarkan hasil analisis data deskriptif didapatkan gambaran bahwa (1) pengetahuan awal mahasiswa 35\% termasuk kategori tinggi, 41\% kategori sedang dan $24 \%$ kategori rendah; (2) self esteem matematis $29 \%$ kategori tinggi dan rendah serta $41 \%$ kategori sedang; (3) kemampuan berpikir logis 24\% kategori tinggi, 65\% kategori sedang dan $12 \%$ kategori rendah. Sedangkan berdasarkan analisis regresi dan anova satu jalur menunjukkan bahwa (1) terhadap hubungan yang signifikan antara pengetahuan awal dan self esteem matematis terhadap kemampuan berpikir logis; (2) terdapat perbedaan yang signifikan kemampuan berpikir logis mahasiswa ditinjau dari pengetahuan awal dan self esteem matematis.
\end{abstract}

\begin{abstract}
This study aims to assess the role of prior knowledge, mathematical self-esteem and logical thinking skills. This study is a correlational study with a quantitative approach. The population at the same sample in this study were all students of the Department of Science Education University of Sultan Ageng Tirtayasa first year amounted to 34 students were taken by simple random. Data collection technique used tests of prior knowledge, tests of logical thinking and mathematical self esteem scale. Analysis of the data in this research is the analysis of descriptive statistics, multiple regression analysis and one way ANOVA. Based on the results of descriptive data analysis, it was shown that (1) the prior knowledge of students categorized as high $35 \%$, as midde $41 \%$ and as low $24 \%$; (2) $29 \%$ mathematical self esteem high and low categories and $41 \%$ middle category; (3) the logical thinking high category $24 \%$, middle catehory $65 \%$ and lower catgeory $12 \%$. While based on regression analysis and one way ANOVA shows that (1) the significant relationship between prior knowledge and mathematical self esteem to logical thinking skills; (2) there are significant differences logical thinking skills of students in terms of prior knowledge and mathematical self esteem.
\end{abstract}

Keywords: Prior Knowledeg; Mathematical Self Esteem; Logicak Thinking Skills

\section{PENDAHULUAN}

Pesatnya perkembangan ilmu pengetahuan dan teknologi saat ini menuntut kesiapan sumber daya manusia yang mempunyai ke- mampuan mengambil keputusan yang cepat dan tepat. Kemampuan tersebut mutlak dimiliki oleh setiap individu untuk mencapai kesuksesan hidupnya. Pengambilan keputusan 
yang cepat dan tepat akan dihasilkan oleh individu yang mempunyai kemampuan berpikir yang baik.

Berpikir adalah aktivitas mental yang melibatkan kerja otak untuk memahami sesautu yang dialami atau mencari jalan keluar dari persoalan yang dihadapi. Dalam berpikir juga termuat kegiatan menduga dan menafsir serta melihat kemungkinankemungkinan yang ada, membuat analisi dan sintesis, menalar atau menarik kesimpulan dari premis-premis yang ada, menimbang dan memutuskan.

Biasanya kegiatan berpikir dimulai ketika muncul keraguan dan pertanyaan untuk dijawab atau berhadapan dengan persoalan atau masalah yang memerlukan pemecahan masalah. Menurut Solso (Khodijah, 2006) berpikir adalah sebuah proses dimana representasi mental baru dibentuk melalui transformasi informasi dengan interaksi yang komplek atribut-atribut mental seperti penilaian, abstraksi, logika, imajinasi dan pemecahan masalah. Sedangkan menurut Saragih (2011) menyatakan bahwa berpikir dapat dikatakan sebuah proses untuk menemukan suatu kebenaran atau pengetahuan yang benar dengan melibatkan pengetahuan atau pengalaman yang dimiliki

Dari uraian di atas dapat kita tarik kesimpulan bahwa kemampuan berpikir akan timbul manakala individu tersebut dihadapkan pada suatu masalah dan penyelesaiannya melibatkan pengetahuan atau pengalaman sebelumnya. Tentunya dalam memecahkan masalah dengan bantuan kemampuan berpikir memiliki kaidah atau aturan yang harus diikuti. Kemampuan berpikir yang mengikuti kaidah tertentu disebut dengan logika.

Dalam logika, dipelajari aturan yang harus dipegang agar proses berpikir valid. Untuk memahami logika maka harus mempunyai pengertian yang jelas tentang penalaran, karena penalaran adalah suatu proses berpikir yang mengacu pada hukum atau aturan logika Poedjiadi (Saragih, 2011). Dengan demikian dapat dikatakan bahwa penalaran adalah proses berpikir logis.

Menurut Syaiful (2011) berpikir logis adalah kemampuan berpikir siswa untuk menarik kesimpulan yang sah menurut aturan logika dan dapat membuktikan bahwa kesimpulan itu benar (valid) sesuai dengan pengetahuan-pengetahuan sebelumnya yang sudah diketahui. Sedangkan Sumarto (2006) menyatakan bahwa berpikir logis adalah proses berpikir yang menggunakan penalaran secara konsisten untuk menghasilkan kesimpulan. Masalah atau situasi yang melibatkan berpikir logis memerlukan struktur, hubungan antar fakta, argumentasi dan rangkaian penalaran yang dapat dimengerti. Adapun menurut Sumarmo (1987) mengemukakan bahwa keterampilan berpikir logis merupakan keterampilan yang dimiliki siswa dalam mengemukakan suatu kebenaran berdasarkan fakta.

Berdasarkan beberapa pendapat di atas, dapat disimpulkan bahwa berpikir logis adalah sebuah proses berpikir yang menggunakan nalar secara konsisten sesuai dengan aturan yang berlaku untuk sampai pada sebuah kesimpulan. Berpikir logis lebih mengacu pada pemahaman pengertian, kemampuan aplikasi, kemampuan analisis, kemampuan sintesis, bahkan kemampuan evaluasi untuk membentuk kecakapan (suatu proses).

Berdasarkan beberapa kajian tentang berpikir baik itu berpikir logis, kritis maupun kreatif menunjukkan bahwa unsur internal dalam diri indivdu sangat mempengaruhi pengoptimalan kemampuan berpikir tersebut, salah satu unsur internal tersebut adalah self esteem (Hernawati, 2014; Happy \& Widjajanti, 2014). Self esteem merupakan aspek psikologis yang memberikan kontribusi yang baik terhadap keberhasilan siswa dalam domain akademik. Hal ini sesuai dengan pendapat Young \& Hofmann (2004) yang menyatakan bahwa self esteem mempunyai hubungan dengan sejumlah faktor kehidupan diantaranya adalah kesuksesan siswa di sekolah.

Individu dengan self esteem yang tinggi cenderung percaya dalam situasi sosial yang dihadapi dan percaya diri dalam menangani tugas-tugas yang dihadapinya, mempertahankan rasa keingintahuannya secara alami dalam belajar serta memiliki semangat dan antusias ketika menghadapi tantangan baru. Sebaliknya individu yang self esteemnya rendah menghindari situasi dimana situasi tersebut berpotensi membuat dirinya merasa malu dihadapan orang lain (Lawrence, 2006). 
Selain faktor self esteem yang berkaitan dengan aspek afektif, aspek kognitif lain yang turut memberikan kontribusi adalah pengetahuan awal. Pengetahuan awal merupakan pengetahuan atau pengalaman sebelumnya yang dimiliki oleh individu, pengeahuan ini menjadi modal bagi individu untuk mencapai pengetahuan baru atau memecahkan permasalahan yang sejenis atau permasalahan yang baru ditemui. Hal ini sejalan dengan pendapat Nur (2000) yang menyatakan bahwa pengetahuan awal adalah kumpulan pengetahuan dan pengalaman seseorang yang diperolehnya selama perjalan hidupnya dan akan dibawa kepada suatu pengalaman belajar baru.

Individu yang mempunyai pengetahuan awal yang baik akan memperoleh pengetahuan baru yang baik pula, dan sebaliknya. Dengan begitu untuk mengoptimalkan kemampuan berpikir logis maka pengetahuan awal harus sudah dimiliki terlebih dahulu oleh individu. Hal ini juga sejalan dengan beberapa penelitian yang dilakukan oleh (Kadir \& Masi, 2014; Syahbana, 2012; Ramdani, 2011; Ismamuza, 2011; Retnawati, 2009;) yang menyatakan bahwa pengetahuan awal mempunyai peranan yang penting dalam kemampuan berpikir.

Dari paparan di atas maka untuk mengoptimalkan kemampuan berpikir logis adalah dengan mengoptimalkan terlebih dahulu pengetahuan awal dan self esteem. Untuk dapat mengoptimalkan kedua aspek tersebut maka perlu dilakukan kajian awal secara deskriptif untuk masing-masing aspek agar dapat merancang bahan ajar dan model pembelajaran yang sesuai. Maka penelitian ini akan mengkaji peranan pengetahuan awal dan self esteem matematis terhadap kemampuan berpikir logis mahasiswa.

Berdasarkan uraian di atas, maka rumusan masalah dalam penelitian ini adalah sebagai berikut:

1. Bagaimanakah gambaran pengetahuan awal dan self esteem matematis terhadap kemampuan berpikir logis mahasiswa?

2. Apakah terdapat hubungan yang signifikan antara pengetahuan awal dan self esteem matematis terhadap kemampuan berpikir logis mahasiswa?
3. Apakah terdapat perbedaan kemampuan berpikir logis mahasiswa ditinjau dari pengetahuan awal dan self esteem matematis?

\section{METODE}

Penelitian ini bertujuan untuk mengungkapkan gambaran dan pengetahuan awal dan self esteem matematis terhadap kemampuan berpikir logis serta perbedaannya. Dari tujuan tersebut maka jenis penelitian ini adalah penelitian korelasional dengan pendekatan kuantitatif. Proses analisis data dalam bentuk kuantitatif yang kemudian diolah dengan statistic baik deskriptif maupun inferensial dan hasilnya dideskripsikan.

Variabel yang diamati dalam penelitian ini yaitu, pengetahuan awal $\left(X_{1}\right)$, Self esteem matematis $\left(X_{2}\right)$ dan Kemampuan berpikir logis $(Y)$. Berikut gambar tata hubung antar variable.

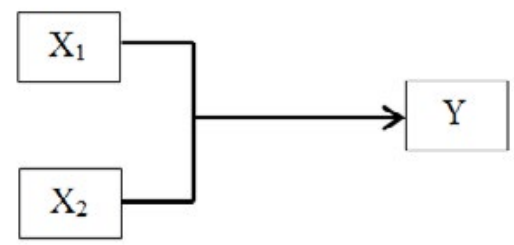

Gambar 1. Tata Hubung Variabel

Penelitian ini dilaksanakan di Jurusan Pendidikan IPA FKIP Universitas Sultan Ageng Tirtayasa. Pemilihan lokasi berdasarkan pada pertimbangan yaitu memudahkan terciptanya kolaborasi antara peneliti dengan mahasiswa serta sudah terjalin hubungan antara peneliti dan subjek yang akan diteliti, dalam hal ini subjek yang diteliti bersedia membantu peneliti selama proses penelitian. Populasi sekaligus sampel dalam penelitian ini adalah seluruh mahasiswa Jurusan Pendidikan IPA yang berjumlah 34 mahasiswa tahun akademik 2016/2017.

Instrument dalam penelitian ini terdiri dari instrument tes dan non tes. Instrument tes yaitu tes pengetahuan awal dan tes kemampuan berpikir logis. Adapun non tes yaitu skala self esteem matematis. Berikut adalah penjelasan masing-masing instrument.

1. Tes Pengetahuan Awal 
Pengetahuan awal adalah kemampuan atau pengetahuan yang dimiliki mahasiswa sebelum pembelajaran berlangsung. Pemberian tes pengetahuan awal ini bertujuan untuk mengetahui pengetahuan siswa sebelum pembelajaran dan digunakan untuk penempatan siswa berdasarkan pengetahuan awal matematisnya.

Pengetahuan awal mahasiswa diukur melalui seperangkat soal tes kemampuan dasar matematika tentang logika matematika. Tes ini berupa soal pilihan ganda yang diperluas berjumlah 10 butir pertanyaan. Berdasarkan skor pengetahuan awal matematika yang diperoleh, siswa dikelompokkan ke dalam tiga kelompok, yaitu siswa kelompok tinggi, sedang, dan rendah.

\section{Tes Kemampuan Berpikir Logis}

Tes kemampuan berpikir logis matematis disusun dalam bentuk uraian dengan jumlah 10 butir pertanyaan. Tes kemampuan berpikir logis dibuat untuk mengukur kemampuan berpikir logis matematis mahasiswa. Jenis berpikir logis yang diukur adalah penalaran induktif dan deduktif.

\section{Skala Self Esteem Matematis}

Skala ini digunakan untuk penggolongan self esteem dengan menggunakan skala Likert dengan jumlah 25 butir pernyataan. Adapun self esteem yang diukur dalam penelitian ini adalah penilaian seseorang terhadap kemampuan (capability), keberhasilan (successfulness), kebermanfaatan (significance), dan kelayakan (worthiness) dirinya dalam matematika.

Teknik analisis data terbagi menjadi dua yaitu analisis statistic deskriptif dan analisis inferensial. Analisis deskriptif bertujuan untuk menggambarkan data ketiga variable tersebut menurut kategori masing-masing. Sedangkan analisis inferensial digunakan untuk menarik kesimpulan terhadap hipotesis penelitian yang diajukan yaitu untuk melihat ada tidaknya hubungan antar ketiga variable tersebut serta melihat adanya perbedaan kemampuan berpikir logis ditinjau dari pengetahuana awal dan self esteem matematis. Sebelum dilakukan analisis inferensial, terlebih dahulu dilakukan uji persyaratan data.

\section{HASIL DAN PEMBAHASAN}

\section{Deskripsi Data}

Data pengetahuan awal diperoleh dari tes pengetahuan awal berbentuk pilihan ganda yang diperluas, kemampuan berpikir logis mahasiswa diperoleh dengan tes berbentuk uraian, sedangkan data self esteem matematis diperoleh melalui skala self esteem matematis berbentuk skala likert. Data hasil penelitian dideskripsikan meliputi rerata, simpangan baku, nilai minimum dan nilai maksimum. Pembagian kategori data menggunakan pendekatan acuan normatif.

\section{Pengetahuan Awal}

Tes pengetahuan awal berjumlah 10 butir pertanyaan berbentuk pilihan ganda yang diperluas. Berikut statistik deskriptif pengetahuan awal mahasiswa.

Tabel 1. Statistik Deskriptif Pengetahuan Awal Mahasiswa

\begin{tabular}{ccccc}
\hline $\mathrm{N}$ & Min & Maks & Simp. Baku & Rerata \\
\hline 34 & 2 & 16 & 4,21 & 9,53 \\
\hline \multicolumn{5}{c}{ Skor Maksimal Ideal $=20$} \\
\hline
\end{tabular}

Berdasarkan table 1 di atas, terlihat bahwa rerata pengetahuan awal matematis mencapai 9,53 atau prosentase perolehannya sebesar 47,65\% termasuk ke dalam kategori sedang. Hasil kecenderungan berdasarkan data variable pengetahuan awal mahasiswa daapt dilihat pada diagram berikut ini.

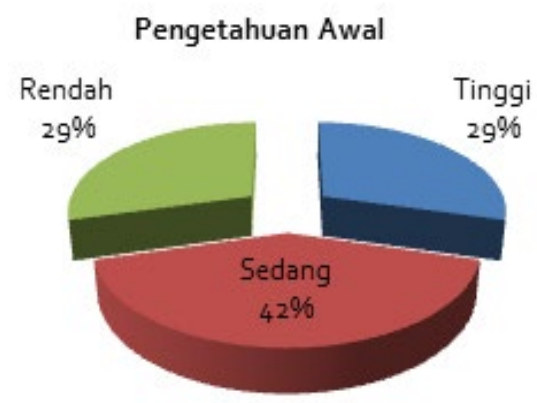

Gambar 2. Persentase Kategori Pengetahuan Awal

Berdasarkan gambar 2 terlihat bahwa sebagian besar mahasiswa memiliki pengeta- 
huan awal sedang terkait materi logika atau sebesar $41 \%$. Sehingga secara prasyarat mahasiswa mempunyai pengalaman atau pengetahuan yang cukup untuk memahami materi logika.

\section{Self Esteem Matematis}

Skala self esteem matematis berjumlah 25 butir pernyataan berbentuk skala likert. Berikut statistik deskriptif self esteem matematis.

Tabel 2. Statistik Deskriptif Self Esteem Matematis

\begin{tabular}{ccccc}
\hline $\mathrm{N}$ & Min & Maks & Simp. Baku & Rerata \\
\hline 34 & 44 & 92 & 11,60 & 65,38 \\
\hline \multicolumn{5}{c}{ Skor Maksimal Ideal = 100 }
\end{tabular}

Berdasarkan table 2 di atas, terlihat bahwa rerata self esteem matematis mencapai 65,38 atau persentase perolehan terhadap skor maksimal ideal sebesar $65,38 \%$ termasuk ke dalam kategori sedang. Hasil kecenderungan berdasarkan data variable self esteem matematis daapt dilihat pada diagram berikut ini.

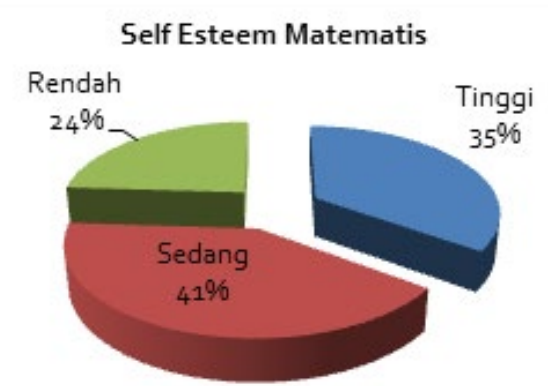

\section{Gambar 3. Persentase Kategori Self Esteem Matematis}

Berdasarkan gambar 3 terlihat bahwa sebagian besar mahasiswa memiliki self esteem matematis yang sedang atau sebesar 41. Hal ini menunjukkan bahwa keyakinan mahasiswa terkait kemampuan matematisnya sudah tergolong baik.

\section{Kemampuan Berpikir Logis}

Tes kemampuan berpikir logis berjumlah 10 butir pertanyaan berbentuk uraian. Berikut statistik deskriptif kemampuan berpikir logis.
Tabel 3. Statistik Deskriptif Kemampuan Berpikir Logis

\begin{tabular}{ccccc}
\hline $\mathrm{N}$ & Min & Maks & Simp. Baku & Rerata \\
\hline 34 & 2 & 16 & 2,85 & 9,18 \\
\hline \multicolumn{5}{c}{ Skor Maksimal Ideal $=17$} \\
\hline
\end{tabular}

Berdasarkan table 3 di atas, terlihat bahwa rerata kemampuan berpikir logis mahasiswa mencapai 9,18 atau persentase perolehan terhadap skor maksimal ideal sebesar $54 \%$ termasuk ke dalam kategori sedang. Hasil kecenderungan berdasarkan data variable kemampuan berpikir logis dapat dilihat pada table berikut ini.

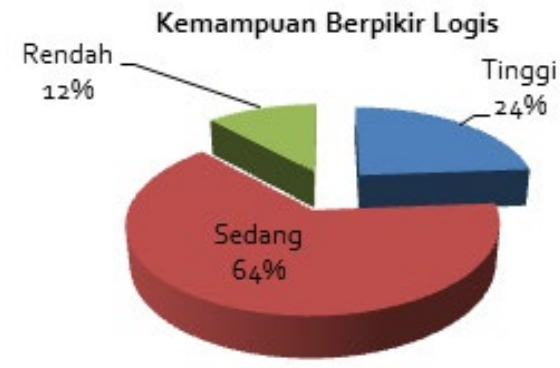

Gambar 4. Persentase Kategori Kemampuan Berpikir Logis

Berdasarkan gambar 4 terlihat bahwa sebagian besar mahasiswa memiliki kemampuan berpikir logis yang sedang atau sebesar $65 \%$. Hal ini menunjukkan bahwa kemampuan berpikir logis mahasiswa baik.

\section{Pengujian Prasyarat Analisis 1.Uji Normalitas}

Uji normalitas data digunakan untuk mengetahui apakah data yang diperoleh berasal dari populasi berdistribusi normal atau tidak. Uji normalitas dilakukan pada ketiga variable yaitu pengetahuan awal, self esteem matematis dan kemampuan berpikir logis. Pengujian normalitas menggunakan Uji Kolmogorov Smirnov.

Table 4. Rangkuman Uji Normalitas

\begin{tabular}{clcc}
\hline No & \multicolumn{1}{c}{ Variabel } & p-value & Sig $(\alpha)$ \\
\hline 1 & Pengetahuan Awal & 0,050 & \\
2 & Self Esteem Matematis & 0,200 & $5 \%$ \\
3 & Kemampuan Berpikir Logis & 0,200 & \\
\hline
\end{tabular}


Berdasarkan table 4.7 di atas terlihat bahwa $p$-value ketiga variable lebih besar dari $5 \%$ maka dapat disimpulkan bahwa ketiga variable berasal dari populasi berdistribusi normal.

\section{Uji Linearitas}

Uji linearitas diperlukan untuk mengetahui apakah variable independen mempunyai hubungan yang linear atau tidak terhadap variable dependennya. Pengujian linearitas dilakukan dengan uji anova.

Table 5. Rangkuman Uji Linearitas

\begin{tabular}{ccc}
\hline Variabel & p-value & Sig $(\alpha)$ \\
\hline Pengetahuan Awal & 0,899 & $5 \%$ \\
Self Esteem Matematis & 0,247 & 5 \\
\hline
\end{tabular}

Berdasarkan hasil pengujian pada table di atas terlihat bahwa variable independen memiliki hubungan yang linear terhadap variable dependen dengan taraf signifikansi lebih dari $5 \%$.

\section{Uii Multikolinearitas}

Uji multikolinearitas digunakan untuk mengetahui ada tidak korelasi yang tinggi antara variable independen. Variable independen dikatakan terjadi multikolinearitas jika nilai VIF kurang dari 10 dan tolerance lebih dari 0,10. Pengujian multikolinearitas dilakukan dengan bantuan program pengolah data. Rangkuman hasil pengujian dapat dilihat pada table berikut.

Table 6. Rangkuman Uji Multikolinearitas

\begin{tabular}{ccc}
\hline Variabel Independen & VIF & Tolerance \\
\hline Pengetahuan Awal & 0,578 & 1,729 \\
Self Esteem Matematis & 0,578 & 1,729 \\
\hline
\end{tabular}

Berdasarkan hasil pengujian seperti terlihat pada table 6 dapat dinyatakan bahwa variable independen pada penelitian ini tidak terjadi problem multikolinearitas dengan nilai VIF semua variable independen kurang dari 10 dan tolerance semua variable lebih dari 0,10.

\section{Pengujian Hipotesis}

Pengujian hipotesis dilakukan untuk mem- buktikan apakah hipotesis yang diajukan benar atau tidak. Terdapat dua teknik pengujian yaitu analisis regresi ganda dan anova satu jalur. Pengujian menggunakan bantuan program pengolahan data. Penjelasan hasil pengujian dalam penelitian ini sebagai berikut.

\section{Pengujian Hipotesis Pertama}

Hipotesis pertama dalam penelitian ini adalah "Terdapat hubungan yang signifikan antara pengetahuan awal dan self esteem matematis terhadap kemampuan berpikir logis mahasiswa". Berikut rangkuman hasil pengujian hipotesis menggunakan uji regresi ganda.

Tabel 7. Rangkuman Uji Regresi Ganda

\begin{tabular}{ccc}
\hline p-value & Sig $(\alpha)$ & Keterangan \\
\hline 0,000 & $5 \%$ & Ho ditolak \\
\hline
\end{tabular}

Berdasarkan table 7 terlihat bahwa nilai p-value kurang dari $5 \%$ atau $0,000<0,05$, artinya Ho ditolak. Hal ini menunjukkan bahwa terdapat hubungan yang signifikan antara pengetahuan awal dan self esteem matematis terhadap kemampuan berpikir logis mahasiswa.

\section{Pengujian Hipotesis Kedua}

Hipotesis kedua dalam penelitian ini adalah "Terdapat perbedaan kemampuan berpikir logis mahasiswa ditinjau dari pengetahuan awal". Hipotesis ini bertujuan membuktikan apakah kemampuan berpikir logis mahasiswa tiap kategori pengetahuan awal berbeda atau tidak. Berikut rangkuman hasil uji anova satu jalur.

\begin{tabular}{ccc}
\multicolumn{3}{c}{ Tabel 8. Uji Anova Satu Jalur } \\
\hline$p$-value & Sig $(\alpha)$ & Keterangan \\
\hline 0,000 & $5 \%$ & Ho ditolak \\
\hline
\end{tabular}

Berdasarkan table 8 di atas menunjukkan bahwa $p$-value kurang dari $5 \%$ yang artinya terdapat perbedaan kemampuan berpikir logis mahasiswa ditinjau dari pengetahuan awal. Adapun untuk melihat kategori mana saja yang berbeda maka perlu dilakukan uji lanjutan yaitu dengan uji Tukey HSD. Berikut rangkuman uji lanjutan. 
Tabel 9. Uji Lanjutan Tukey HSD

\begin{tabular}{ccc}
\hline Pasangan Kategori & p-value & Keterangan \\
\hline Tinggi $><$ Sedang & 0,001 & Terdapat \\
Tinggi $><$ Rendah & 0,000 & perbedaan \\
Sedang $><$ Rendah & 0,018 & \\
\hline
\end{tabular}

Tabel di atas menunjukkan bahwa masing-masing kategori pengetahuan awal mempunyai perbedaan kemampuan berpikir logis. Kemampuan berpikir logis mahasiswa yang mempunyai pengetahuan awal tinggi lebih baik dibandingkan dengan mahasiswa yang mempunyai pengetahuan awal sedang dan rendah.

\section{Pengujian Hipotesis Ketiga}

Hipotesis ketiga dalam penelitian ini adalah "Terdapat perbedaan kemampuan berpikir logis mahasiswa ditinjau dari self esteem matematis". Hipotesis ini bertujuan membuktikan apakah kemampuan berpikir logis mahasiswa tiap kategori self esteem matematis berbeda atau tidak. Berikut rangkuman hasil uji anova satu jalur.

Tabel 10. Uji Anova Satu Jalur

\begin{tabular}{ccc}
\hline$p$-value & Sig $(\alpha)$ & Keterangan \\
\hline 0,000 & $5 \%$ & Ho ditolak \\
\hline
\end{tabular}

Berdasarkan table 10 di atas menunjukkan bahwa $p$-value kurang dari $5 \%$ yang artinya terdapat perbedaan kemampuan berpikir logis mahasiswa ditinjau dari self esteem matematis. Adapun untuk melihat kategori mana saja yang berbeda maka perlu dilakukan uji lanjutan yaitu dengan uji Tukey HSD. Berikut rangkuman uji lanjutan.

Tabel 11. Uji Lanjutan Tukey HSD

\begin{tabular}{ccl}
\hline Pasangan Kategori & p-value & \multicolumn{1}{c}{ Keterangan } \\
\hline Tinggi $><$ Sedang & 0,001 & $\begin{array}{l}\text { Terdapat perbe- } \\
\text { daan }\end{array}$ \\
Tinggi $><$ Rendah & 0,000 & $\begin{array}{l}\text { Terdapat perbe- } \\
\text { daan }\end{array}$ \\
Sedang $><$ Rendah & 0,385 & $\begin{array}{l}\text { Tidak terdapat } \\
\text { perbedaan }\end{array}$ \\
\hline
\end{tabular}

Tabel di atas menunjukkan bahwa kemampuan berpikir logis mahasiswa yang mempunyai pengetahuan awal tinggi, sedang dan rendah berbeda. Sedangkan untuk mahasiswa yang mempunyai pengetahuan awal sedang dan rendah tidak berbeda secara signifikan.

\section{Pembahasan}

Penelitian ini bertujuan untuk mengetahui peranan variable pengetahuan awal dan self esteem matematis terhadap kemampuan berpikir logis serta mengetahui apakah terdapat perbedaan kemampuan berpikir logis mahasiswa ditinjau dari pengetahuan awal dan self esteem matematis pada mahasiswa jurusan pendidikan IPA. Uraian sebelumnya telah dibahas hasil perhitungan dengan menggunakan bantuan software pengolah statistic untuk deskripsi data masing-masing variable beserta perhitungan hipotesis. Pembahasan hasil penelitian secara rinci dapat diuraikan sebagai berikut.

Berdasarkan hasil penelitian yang telah dilakukan dengan uji regresi ganda dapat disimpulkan bahwa terdapat pengaruh pengetahuan awal dan self esteem matematis terhadap kemampuan berpikir logis mahasiswa. Pengaruh tersebut dapat dilihat dari nilai p-value yaitu o,000 kurang dari o,005. Hal ini menunjukkan bahwa variable pengetahuan awal dan self esteem matematis berpengaruh secara signifikan terhadap kemampuan berpikir logis.

Persamaan regresi yang terbentuk yaitu $Y=-0,267+0,319 X_{1}+0,098 X_{2^{\prime}}$ Persamaan tersebut menunjukkan bahwa apabila $X_{1}$ dan $\mathrm{X}_{2}$ meningkat menjadi 10 poin, maka $Y$ bertambah menjadi 3,903. Grafik menunjukkan hubungan yang positif, yang artinya semakin nilai variable bebas bertambah maka nilai variable terikatnya bertambah pula.

Pengetahuan awal dan self esteem matematis berpengaruh terhadap kemampuan berpikir logis mahasiswa. Hal ini sejalan dengan penelitian Muchlishin (2010) yang menyatakan bahwa pengetahuan awal berpengaruh terhadap hasil belajar. Hasil belajar terdiri dari aspek kognitif yang berkaitan erat dengan kemampuan berpikir. Seseorang yang memiliki pengetahuan awal yang baik akan memperoleh pengetahuan yang baik pula. Hal ini terkait dengan pengalaman dan pengetahuan sebelumnya, seseorang yang mempunyai pengalaman terkait materi yang akan disampaikan akan mengalami proses asimila- 
si yang cepat dibandingkan dengan individu yang sebelumnya tidak mempunyai pengalaman tersebut.

Adapun menurut Adiputra (2015) menunjukkan bahwa self esteem berpengaruh terhadap prestasi belajar mahasiswa. Namun hubungan tersebut tidak kuat. Mahasiswa yang memiliki self esteem yang tinggi akan membangkitkan rasa percaya diri, rasa yakin akan kemampuan diri, rasa berguna serta selalu berpikir positif atas segalanya. Sebaliknya individu yang mempunyai self esteem yang rendah akan menunjukkan perilaku yang tidak percaya diri, merasa gagal dan kecewa apabila melakukan sesuatu yang tidak sesuai harapan.

Berdasarkan hasil analisis data menunjukkan bahwa kontribusi pengetahuan awal dan self esteem matematis secara bersamasama sebesar $62,20 \%$. Sisanya dipenggaruhi oleh variable lain. Kontribusi tersebut tergolong tinggi sehingga pengaruh pengetahuan awal dan self esteem signifikan.

\section{SIMPULAN}

Berdasarkan analisis data dan pembahasan hasil penelitian tentang peranan pengetahuan awal dan self esteem matematis terhadap kemampuan berpikir logis mahasiswa, dapat disimpulkan yaitu:

1. Terdapat pengaruh yang signifikan antara pengetahuan awal dan self esteem matematis terhadap kemampuan berpikir logis mahasiswa.

2. Terdapat perbedaan kemampuan berpikir logis mahasiswa ditinjau dari pengetahuan awal.

3. Terdapat perbedaan kemampuan berpikir logis mahasiswa ditinjau dari self esteem matematis.

\section{DAFTAR PUSTAKA}

Adiputra, S. (2015). Keterkaitan Self Efficacy dan Self Esteem Terhadap Prestasi Belajar Matematika. Jurnal Fokus Konseling Volume 1 No. 2, Agustus 2015 Halaman 151-161.

Happy \& Widjajanti. (2014). Keefektifan PBL Ditinjau dari Kemampuan Berpikir Kritis dan Kreatif Matematis, Serta Self-Esteem Siswa SMP. Jurnal Riset Pendidikan Matematika, Volume 1, Nomor 1, Mei 2014.

Hernawati, T. (2014). Meningkatkan Kemampuan Berpikir Kreatif dan Logis Matematis serta Self-Es- teem Siswa SMP Melalui Pembelajaran dengan Pendekatan Open-Ended. Tesis SPs UPI Bandung. Tidak Diterbitkan.

Ismamuza, D. (2011). Kemampuan Berpikir Kritis Matematis Ditinjau dari Pengetahuan Awal Siswa. Jurnal Pendidikan Matematika, Volume 2 Nomor 1, Januari 2011.

Kadir \& Masi La. (2014). Penggunaan Konteksdan Pengetahuan Awal Matematika dalam Pembelajaran Keterampilan Berpikir Kreatif Siswa. Jurnal Pendidikan Matematika Volume 5 Nomor 1 Januari 2014.

Khodijah, N. (2006). Psikologi Belajar. Palembang: IAIN Raden Fatah Press.

Lawrence, D. (2006). Enhancing self-esteem in the classroom (3rded.). London: Paul Chapman Publishing.

Muchlishin. (2010). Hubungan antara Kemampuan Awal Matematika dan Motivasi Berprestasi dengan $\mathrm{Ha}$ sil Belajar Matematika Materi Segitiga dan Segi Empat Kelas VII SMP Askhabul Kahfi Polaman Mijen Semarang Tahun 2009/2010. Semarang: Skripsi Pendidikan Tadris Matematika Fakultas Tarbiyah IAIN Walisongo.

Nur. (2000). Strategi-Strategi Belajar. Surabaya: Unesa Press.

Ramdani. (2011). Pembelajaran untuk Meningkatkan Kemampuan Berpikir Matematika Tingkat Tinggi Melalui Pendekatan Contextual Teaching and Learning (CTL). Prosiding SNaPP: Sains dan Teknologi.

Retnawati. (2009). Pengaruh Kemampuan Awal dan Kemampuan Berfikir Logis/penalaran terhadap Kemampuan Matematika. Universitas Negeri Yogyakarta.

Saragih, S. (2011). Penerapan Pendekatan Pembelajaran Matematika Realistik dan Kelompok Kecil untuk Meningkatkan Kemampuan Keruangan, Berpikir Logis, dan Sikap PositifTerhadap Matematika Kelas VIII. Disertasi SPs UPI Bandung: Tidak diterbitkan.

Sumarmo, U. (1987). Kemampuan Pemahaman dan Penalaran Matematika Siswa SMA Dikaitkan dengan Kemampuan Penalaran Logik Siswa dan Beberapa Unsur Proses Belajar Mengajar. Disertasi FPS IKIP Bandung: Tidak Diterbitkan.

Sumarto. (2006). Konsep Dasar Berpikir; Pengantar ke Arah Berpikir Ilmiah. Makalah Seminar Akademik HUT Ke-40 FE Universitas Nasional "Veteran" Jawa Timur.

Syahbana. (2012). Peningkatan Kemampuan Berpikir Kritis Matematis Siswa SMP Melalui Pendekatan Contextual Teaching And Learning. Edumatica Volume 02 Nomor 01, April 2012.

Syaiful. (2011). Peningkatan Kemampuan Berpikir Logis, Kemampuan Pemecahan Masalah Matematis, dan Sikap Siswa Terhadap Matematika Melalui Pendidikan Matematika Realistik. Disertasi SPs UPI Bandung: Tidak Diterbitkan.

Young, E. L., \& Hoffmann, L. L. (2004). Self esteem in children: Strategies for parents and educators. Dalam A. S. Canter et. al. (Eds), Helping children at home and school II: Strategies for families and educators (pp 87-89 (S5)). Bethesda, MD: NASP Publications. 